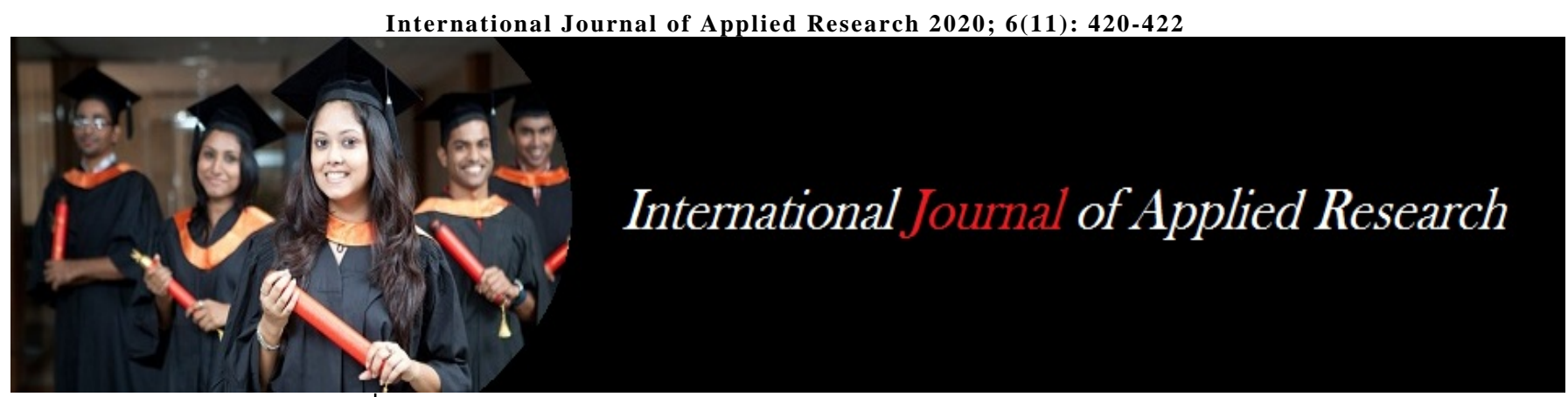

ISSN Print: 2394-7500 ISSN Online: 2394-5869 Impact Factor: 8.4 IJAR 2020; 6(11): 420-422 www.allresearchjournal.com

Received: 26-08-2020 Accepted: 08-10-2020

Dr. Shailendra Singh Sengar Assistant Professor, Samhita and Siddhanta, Chandraskhar Singh Ayurved Sansthan,

Kaushambi, Prayagraj, Uttar Pradesh, India

Dr. Ramnihor Tapsi Jaiswal Lecturer, Samhita and Siddhanta, Govt. PG Ayurved College and Hospital, Chaukaghat, Varanasi, Uttar Pradesh, India

Dr. Jyoti Singh PG Scholar, Samhita and Siddhanta, Govt.PG Ayurved College and Hospital, Chaukaghat, Varanasi, Uttar Pradesh, India
Corresponding Author: Dr. Shailendra Singh Sengar Assistant Professor, Samhita and Siddhanta, Chandraskhar Singh Ayurved Sansthan, Kaushambi, Prayagraj, Uttar Pradesh, India

\section{Basic principles and contemporary science: A review}

\author{
Dr. Shailendra Singh Sengar, Dr. Ramnihor Tapsi Jaiswal and Dr. Jyoti \\ Singh
}

DOI: $\underline{\text { https://doi.org/10.22271/allresearch.2020.v6.i11g.7959 }}$

\begin{abstract}
Since ancient times Ayurveda is showering us with its principles, it is a flow of knowledge streaming downward from generation to generation. Principles of Ayurveda are derived from the universal law of nature that has changed little through time. With a subjective, objective, and intuitive approaches to gaining knowledge, incorporated with a deep understanding of the unseen intelligence of the universe. The practices of Ayurveda have withstood the test of time. In this 21st century where modern science, on one hand, makes our life much easier on the other hand it also makes it miserable in different aspects of life. It arises many unsolved questions, disturbing urges in the human mind. Ayurveda helps us in excluding out all these disturbing urges problems, lifestyle disorders. In this paper, I want to point out how Ayurveda's basic principles can be helpful and relatable to modern science. Studying and following Ayurveda with contemporary science can help us to raise our personal, social as well as professional life and have a peaceful life.
\end{abstract}

Keywords: Karya - Karan bhav, Pratyaksha pramana, Anumaan pramaan, Yukti pramana

\section{Introduction}

Ayurvedic principles, a connotation of connecting link between Ayurveda and modern science. Thinking of effective utilization of Ayurveda through a better understanding of its fundamental is a recent realization. In modern we always concentrate on the problems or sufferings and work on them never considerate the cause behind the reason. Ayurveda solved the quest, what is the cause of suffering, and how it can be solved through Kaarya Kaarana Siddhanta. By knowing the exact cause and reason we can stop the recurrence of Vyaadhi (disease), which is further examining through Pramana to exclude out the cause.

\section{Material and methods}

Related literary sources from various ayurvedic texts like Padartha Vijanan, Charak Samhita, Sushruta Samhita, and related journals are usd for reviewing.

\section{Rsults and discussion}

Karya karana bhaava: Karya Karana bhava has been described as Sarvatantra Siddhanta of Ayurveda. AcharyaCharaka has quoted nothing in the universe without cause means all the existing matters must have caused.

$$
\begin{aligned}
& \text { न हयेको वर्तते भावो वर्तते नाप्यहेतुकः| } \\
& \text { शीघ्रगत्वात्स्वभावात्त्वभावो न व्यतिवर्तते||५८|| (Ch.Su.1/58) }
\end{aligned}
$$

Karya is an effect which is absent before. But produced later on by the agent's proceeding or act like disease, health, body, therapies, birth and at the end, all are coming after death which means from birth to the end of life, whole life is endowed with this Siddhanta. And the reason behind the above-described effect is the cause. As said before "necessity is the mother of invention" similarly when there is cause there will be an effect. This cause and effect relationship can be seen in the diagnosis and treatment of diseases. The physician who treats is Karana, Karana is also known as Hetu\ Nidaana or Karta (actor). Karya is the manifested stage and Karana is non manifested stage which resides in Karya in subtle form. 
Karya is through which Karana is produced or cause is that form that is produced by the effect.

Karya is the counter correlative of its own nonvisible or manifested Kaarana eg. Clay exists before the manifestation of the pot. Hence earth or clay is the cause of pot.

Kaarina can be categorized into three folds:

1. Samvayi Karana or Upadana Karana (material cause or intimate cause)

2. Asmavayi Karana (efficient cause)

3. Nimitta cause (instrumental cause or occasioning cause)

Samvayi Karana is inseparable union with which effect is produced at the same time. It exists in Karya which is produced from Karana itself in the form of Saamveta. For example, Vastra (cloth) is Samvayi Karana (intimate cause) of the Varna (color of the cloth). The cause which is inseparable until destruction is Samvayi Karana.

Asamvaayi Karana is inseparable united within the same object with the effect. For example, the Conjunction of tantu produces Vastra and Varna. If tantu is not arranged properly it will never produce Vastra as well as Varna. Here conjunction of Tantu with Vastra and Vrana is Asamvayi Karana.

Nimitta Karana helps Samvayi and Asamvayi Karana to produce effects and after that Karana detached from Karya itself. For example, in the production of cloth, shuttle and loom are the Nimitta Karana. Loom and shuttle detached from the cloth after its production. This is Nimitta Karana.

The manifestation of diseases also seeks these factors: Samvayi, Asamavayi, and Nimitta Karana as Dosha Vaishamya, Dosha Dushya Sammurchhnaand MithyaAhara Vihar respectively.

Charaka states Karana as a physician or actor who acts as the doer and cause of action. As a physician is a causative factor for the alleviation of diseases through treatment, so the physician is Karana. And Karya is the effect that agent proceeds example, normalcy of Dosha is the effect on treatment.

Thus, because of different Karana or cause many diseases to exist, which is proved by Karya and Karana Bhaav. In the absence of the Karana (Nidaana) Karya i.e disease will never manifest. And in the absence of Karana i.e Chikitsa Chatushpada alleviated diseases will never manifest. Hence, Karya is produced when Karana exists.

Pramana leads to an important role in acquiring descriptive and complete knowledge. It can be considered a tool to gain knowledge. There no value of anything is it is not supported by Pramana.

It has four folds of classification:

1. Aptopdesha Pramana

2. Pratyaksha Pramana

3. Anumaan Praman (Inference)

4. Aupamaya Pramana (Analog)

Pratyaksha Pramana: It is also known as perception or direct immediate cognition. It is one of the best methods of knowledge, in which by direct contact of sense organ knowledge can be obtained. A physician should use all his senses except taste sensation during examining a patient. For example, heart and respiratory sound, gargling sound in the stomach, crept in joints, disturbed voice of the patient can be heard by ear. Similarly, color, shapes, signs of diseases, natural and unnatural changes in the body are examined through eyes, the normal and abnormal smell of the body, body wastes, medicine sense by the nose. Thus Pratyaksha Pramana helps to examine the patient.

According to Charaka, there are very few factors perceivable through eyes in comparison to those which are invisible. Although modern technologies have replaced and made examinations easy through instruments like USG, MRI, CT scan, etc. but modern science can't claim that made everything visible.

Anumaan Pramaan: Another fold of Pramaan or means of knowledge that is perceived by the present, past, and future is Anumaan Pramaan. The literary meaning of Anumaan is knowing after. This knowledge can be gained through perceived or already experienced knowledge. For example:

1. By seeing the smoke, we think of fire- knowledge of present or commonly observed events. It can be correlated with cross-sectional study design or prevalence studies.

2. By seeing a newborn, we think of sexual intercourseknowledge of past or effect to cause. This can be correlated with case-control study design or retrospective studies.

3. By seeing a seed, we think of a plant that will arise from it - knowledge of the future (cause to effect). This can be correlated with prospective cohort study design or longitudinal studies.

Acharya Charaka states a few assumptions we draw through Anumaan Pramaan is, by digestion and metabolism. We can assume the digestive power or power of Jathragni. Restricted joint movement indicates knee injury or arthritis, inflammation, or any degenerative disorder with joints. The morbidity of pathogenic factors can be ascertained by the causative factors if there are more causative factors then the disease will be more severe.

In modern research methodology, Anumaan Pramaan is very important to gain knowledge. In survey researches about various issues like psychological, political, social, etc. questionnaires and interviews are conducted and spcially they are concluded through AnumaanPramaan (logical inference).

Yukti Pramaan: It is an analysis or inferential knowledge or logical reasoning which can be arrived after a careful selfanalysis of various factors. It can be defined as a conclusion drawn based on Pratyaksha and Anumaan Pramaan. It has multidimensional aspects.

It has logical reasoning to establish Karya Karana Bhav. It helps make a diagnosis and treat disease involving multiple Dosha with many confusing symptoms and excluding out true diagnosis from differential diagnosis and availability of few treatment options. Yukti Pramana physician formulates effective treatment based on his knowledge of Aptopadesha, practical experience, intelligence, and analytical skills.

It is an important tool in research methodology to guide rules of logical reasoning and the process of induction and deduction.

\section{Conclusion}

Siddhanta is made after many types of research on a hypothesis or the theory which cannot be science works on principles, without principles or basic law nothing can exist or proved. Karya - Kaaran Bhaav or cause-effect relationship explains that every effect has its specific cause and every specific effect shows its specific cause. Theoretically, the fundamental principle is to be considered 
neither completely true nor completely false though it's all temporary, concerning time and current facts are needed to ascertain or implementing the updated modern science.

\section{References}

1. Charak Samhita. Vidyotini Hindi Vyakhya1st part by Pandit Kashinath Pandey and Dr. Gorakhnath Chaturvedi, 2011, 814.

2. Textbook of Padarth Vijanan by Dr. K.V.L Narasimhacharyulu, Chaukhambha Krishnadas Academy Varanasi, 345.

3. Textbook of Padarth Vijanan by Dr. K.V.L Narasimhacharyulu, Chaukhambha Krishnadas Academy Varanasi, 346.

4. Textbook of Padarth Vijanan by Dr. K.V.L Narasimhacharyulu, Chaukhambha Krishnadas Academy Varanasi, 347 to 349.

5. Textbook of Padarth Vijanan by Dr. K.V.L Narasimhacharyulu, Chaukhambha Krishnadas Academy Varanasi, 189.

6. Textbook of Padarth Vijanan by Dr. K.V.L Narasimhacharyulu, Chaukhambha Krishnadas Academy Varanasi, 193.

7. Ayurvedopjeevak Siddhanta (Secondary Principles of Ayurveda) by prof. Om Prakash Upadhyaya, Chaukhambha Sanskrit Bhawan Varanasi, 9.

8. Ayurvedopjeevak Siddhanta (Secondary Principles of Ayurveda) by Prof. Om Prakash Upadhyaya, Chaukhambha Sanskrit Bhawan Varanasi, 14.

9. Basics of research methodology and medical statistics by Dr. Bilal Ahmad Wani and Dr. Shaheen Ahmad Mir, Ayurved Sanskrit Hindi Pustak Bhandar, Jaipur, 78

10. Basics of research methodology and medical statistics by Dr. Bilal Ahmad Wani and Dr. Shaheen Ahmad Mir, Ayurved Sanskrit Hindi Pustak Bhandar, Jaipur, 79.

11. Basics of research methodology and medical statistics by Dr. Bilal Ahmad Wani and Dr. Shaheen Ahmad Mir, Ayurved Sanskrit Hindi Pustak Bhandar, Jaipur, 80.

12. Basics of research methodology and medical statistics by Dr. Bilal Ahmad Wani and Dr. Shaheen Ahmad Mir, Ayurved Sanskrit Hindi Pustak Bhandar, Jaipur, 81.

13. A comprehensive review of the Kaarya- Kaarana Siddhanta (Theory of cause and effect) in Ayurveda, Dr. Harish J. Purohit, and Dr. Vaibhav Dadu www.wjpps.com 2016;5:1.

14. Concept of Kaarya Kaarana Siddhanta: A review by Madhumita Panigrahi, Mahesh Kumar Vyas, Arjun Singh Baghel, Hitesh Vyas January www.stmjournals.com, 2017;4:3. 